Article

\title{
Sustainability Development in Mathematics Education-A Case Study of What Kind of Meanings Do Prospective Class Teachers Find for the Mathematical Symbol " $\frac{2}{3}$ "?
}

\author{
Jorma Joutsenlahti ${ }^{1, *}$ and Päivi Perkkilä ${ }^{2}$ \\ 1 Faculty of Education and Culture, Tampere University, 33014 Tampere, Finland \\ 2 Faculty of Education, University of Jyväskylä, 40014 Jyväskylä, Finland; paivi.m.perkkila@jyu.fi \\ * Correspondence: jorma.joutsenlahti@tuni.fi
}

Received: 26 November 2018; Accepted: 14 January 2019; Published: 16 January 2019

check for updates

\begin{abstract}
In this article, our focus is on sustainable development in mathematics education from the point of view of teacher training. The aim was to develop prospective teachers' content knowledge and pedagogical content knowledge of school mathematics. As a case study, we chose the mathematical symbol "a/b", and examined how prospective class teachers in Finland connect it to the concepts of fraction, ratio, division, rational number or probability. Mathematics textbooks often have a central role in lessons, and they affect strongly how pupils understand concepts and the relationships between them. We chose languaging as a multi-semiotic approach to interpreting what kind of meanings the prospective class teachers gave the mathematical symbol " $\mathrm{a} / \mathrm{b}$ ". The results show that some of these concepts are difficult to see at the same time from the given mathematical symbol. The concept of ratio is particularly difficult for prospective class teachers to interpret. Pictorial presentation supported the interpretations. Mathematics learning materials and teacher education should develop in accordance with the results of the study.
\end{abstract}

Keywords: fractions; multi-semiotic approach; languaging; prospective class teacher; content knowledge; pedagogical content knowledge

\section{Introduction}

\subsection{Sustainable Development of Education}

The concept of sustainability is often associated with ecological and economic issues, but it also applies in the educational realm. For example, even without an explicit awareness of the concept, already in 1657 Comenius dedicated a chapter of his book "Didactica Magna" to the "foundations of lasting teaching and learning" [1]. The United Nations (UN) has developed an agenda for 2030 Agenda for Sustainable Development, where education is seen as one of the main cornerstones for sustainable development [2]. The main purpose in the fourth goal of this agenda is to ensure inclusive and quality education for all and promote lifelong learning. It is commonly known that mathematics acts as a gatekeeper in education: those students who have a good knowledge of mathematics are more likely to have better scores and end with better educational trajectories than those who underperform in this subject [3].

Our focus is on sustainable development in prospective class teachers' mathematics education. Following Shulman [4], we distinguish three categories of teacher's content knowledge: subject matter content knowledge, pedagogical content knowledge and curricular knowledge. These categories are 
applied to the teaching of primary school mathematics. We need to take account of all three categories in developing mathematics teaching toward greater sustainability in achieving better learning results.

In the Finnish Core Curriculum 2014 (FCC) [5], the word sustainable is mentioned 176 times. In the general part of FCC, sustainable development is seen as a "school's role in building a sustainable future that can be strengthened in the organization of education". The basic idea of sustainable development in the FCC can be seen in the light of the UN's agenda for 2030 Agenda for Sustainable Development, in which one of the main purposes is to ensure inclusive and quality education for all and promote lifelong learning. The FCC has a major role in determining the contents of mathematics textbooks, which in Finland are the most important factor influencing the structure of mathematics lessons at primary school [6]. Thus, the textbooks are an important tool to ensure sustainability development in mathematics education.

\subsection{The Bases of Sustainable Development in Mathematics Education}

Mathematical content knowledge requires understanding of the facts or concepts of a domain. This means that teachers must understand the structure of mathematics. Teachers must not only be capable of defining mathematical concepts, but they also must be able to explain why a mathematical concept is worth knowing and understanding, and how it relates to other concepts in both theory and practice. The second category of content knowledge is pedagogical content knowledge, which includes the teaching dimension of mathematical content knowledge. In other words, pedagogical content knowledge requires the teachers to have the skill of teaching mathematics that make it understandable to others. Because there is no single most effective way of teaching, teachers must have at hand alternative approaches, some of which might be based on the results of current research, whereas others are born of experience. Pedagogical content knowledge also involves an understanding of how pupils learn mathematics, and what makes the learning of a specific topic easy or difficult. The third category of content knowledge is curricular knowledge, which includes teachers' skills and abilities to relate the mathematical content of a given lesson to topics or issues being discussed in other classes. At the same time, teachers need to have a grasp of the mathematical topics and issues taught in the mathematical subject area during the preceding and later years in school, and the teaching materials that embody them. In building a sustainable mathematics teacher education, and class teacher education, we understand that both content and process are important in teaching professionals. Mathematical content knowledge includes knowledge of mathematical structures, pedagogical knowledge of the general and specific topics of mathematics and specialized curricular knowledge [4].

If a teacher has too narrow a pedagogical content knowledge and curricular knowledge, then the teacher might see mathematics only as "rules" and "procedures". In that case, they might concentrate on mathematics teaching only in terms of calculating, practicing and perfecting such rules and procedures, without trying to understand the underlying concepts and structures [7]. In this way, the teacher does not build a solid picture of mathematical content knowledge for their students.

\subsection{A Case: Fractions and Meanings of Symbol " $a / b$ "}

We consider the concept of fraction and the symbol "a/b" as a case from school mathematics. The research (e.g., [8-11]) shows that fractions are one of the most challenging areas in school mathematics. Pupils, prospective class and subject teachers, and sometimes even experienced teachers, have trouble with fractions, especially understanding fractions as numbers that extend the whole number system to rational numbers (e.g., [12,13]). To understand this extension, one must have a clear picture of the different meanings of fractions. In Finnish mathematics textbooks, these different meanings of fractions are introduced separately without clear context, and are often taught emphasizing a procedural perspective. Fractions have interesting features compared to other numbers: two fractions could have different numerator and denominator, but they are equal (equivalent fractions). 
The conceptual picture of the fraction and its different meanings receive less attention than they should [14].

When moving from integers to rational numbers, a conceptual change needs to take place in the pupils' thinking. A conceptual change means a fundamental change in a pupil's previous thinking [15]. According to Vosniadou [16-18], pupils tend to form an "inconsistent synthesis" of earlier knowledge and new lesson material, as the earlier data structure is often unconscious as well. In mathematics, such a phenomenon has been observed in the case of a number concept, where the nature of the natural number and the rules of operations have been found to transfer wrongly, for example, to the thinking and understanding of rational numbers $[15,19]$.

Nowadays, mathematics textbooks play a powerful role in the teaching and learning of mathematics. It is commonly known that teachers trust textbooks, and base a major part of their teaching on them [20,21]. This gives support for Perkkilä's [22] findings, who showed that, in Finnish primary-level mathematics, textbooks and teacher guides play a crucial role in teachers' work. Teacher guides usually include pedagogical tips and instructions, mathematical content knowledge, academic year plans for mathematics, exact lesson plans, etc. Teachers very often follow the suggestions of teacher guides on what to teach and how to teach, and usually the teaching materials also prescribe the order in which the content should be taught. Consequently, even if textbooks are written for the pupils, they can also be mediators between the intended curriculum and the implemented curriculum $[19,20]$.

In principle, prospective class teachers have enough content knowledge and curricular knowledge of each of the concepts of fraction, ratio and division, but there could be problems in the understanding of how the concepts are related to each other, and how we should take account of it in mathematics teaching. This is an important part of pedagogical content knowledge, so it is interesting to gain a picture of how prospective class teachers understand the different meanings of fractions. During the first six grades, it is class teachers who are responsible for the mathematics teaching. They often feel themselves uncertain in mathematics [22], which is why they tend to follow the contents of textbooks and teacher guides strictly, which then influences the pupils' view of mathematical concept and knowledge. Due to this, pupils' understanding of the different meanings of mathematical concepts and meanings-in this case, the different meanings of fractions-may be based on the content of textbooks. In the course of the article, we refer to prospective class teachers as the students, and we use " $2 / 3$ " as standing for the symbol " $\frac{2}{3}$ ".

\section{Theoretical Background}

\subsection{Multiple Meanings of Symbol " $a / b$ " in School Mathematics}

Because of the above, it is interesting to examine the conceptual interpretations of symbol " $\mathrm{a} / \mathrm{b}$ ", for which the mathematics textbooks give meanings depending on the content area mathematics. It is not our intention to discuss in this article the theoretical relationships between the concepts to which symbol "a/b" is connected.

Researchers have found different subconstructs which are connected to the symbol " $\mathrm{a} / \mathrm{b}$ ". Each subconstruct creates a context for the fraction that gives it a contextual meaning. These subconstructs also refer to the extension of whole numbers to rational numbers. Existing studies (e.g., [23-25]) have considered the meanings of the symbol "a/b" from the point of view of the fraction concept. Pantziara and Philippou [23] highlighted the fact that pupils' difficulties in fraction learning is linked to its multifaceted construct. From this point of view, they described the following five subconstructs: part-whole, ratio, quotient, measure, and operator. Stewart [24] also referred to the multifaced construct of fractions in introducing the following subconstructs in her thesis: part-whole relationship: the ratio of the part to the whole; measurement: the position of a number on the number line; operator: a transformation; quotient: division; and ratio: relationship between two quantities. Park, Güler, and McGrory [12] approached fractions in their research framework from the point of four subconstructs to the development of fractions found in history: part-whole: conceptualizing a part 
of a whole as a new unit; measurement: finding fractions from whole numbers through measurement and proportions, addressing the need for a common unit of measurement for two quantities; division: finding the algebraic solution for an equation $\mathrm{A}_{\mathrm{X}}=\mathrm{B}$ where $\mathrm{A}$ and $\mathrm{B}$ are whole numbers and $\mathrm{A}$ is nonzero; and set-theoretical: defining rational numbers as a set of ordered pairs consisting of whole numbers. The different meanings of the fraction concept introduced above give quite a good picture of how intricate this concept is $[12,23,24]$; it can be assigned various meanings according to the context in which the concept is used.

In Finnish mathematics textbooks [14], the symbol " $2 / 3$ " has five main interpretations depending on context: (A) fraction (A1 "two thirds of a given whole" or A2 "two of three parts"); (B) rational number ("two thirds"); (C) ratio ("a ratio of two to three"); (D) division ("two divided by three"); and (E) probability ("There is a two-thirds chance of it happening"). The first one (fraction) is divided into two subcategories according to the verbal expressions, for example "two thirds of a given whole" or "two of three parts". We use the six subconstructs as the theoretical framework for the meanings of symbol " $2 / 3$ ".

\section{A. The symbol "a/b" as a fraction and as a part out of a sum of parts.}

The part-whole relationship is considered as the ratio of the part to the whole [23,24]. Beckmann [26] defined the symbol " $\mathrm{a} / \mathrm{b}$ " as a fraction as follows: If $a$ and $b$ are whole numbers and $b$ is not zero, and if an object, collection, or quantity can be divided into b equal parts, then the fraction " $a / b$ " of an object, collection, or quantity is the amount formed by parts (or copies of parts).

The part-whole relationship can be interpreted in two ways depending on the context (cf. the above definition): Firstly (A1), if we take two thirds ("two thirds of a given whole") of a pizza, we take two equal slices out of a pizza cut into three equal pieces. Secondly (A2), if we take two parts out of three ("two of three"), we reinforce the idea of dividing quantities into three equal parts and choosing two of them. Typically, textbooks describe the ratio of a part to the whole as an area model (e.g., as a pie model), and a pie model for " $2 / 3$ " is read for example as two thirds of the pizza. In addition, the part-whole approach may apply when teachers use area models divided into equal parts, or mention that a part of a collection or object can be expressed as a fraction with equal partitioning and counting [12].

\section{B. The symbol " $a / b$ " as a rational number.}

According to Park, Güler and McGrory [12], the roots of the definition of rational numbers are based on a set-theoretical approach. Rational numbers $Q$ are defined as follows:

$$
\left\{\frac{m}{n} \mid m, n \in Z, n \neq 0\right\}
$$

For example, integers are a subset of $Q$, and on the other hand $Q$ is a subset of real numbers. Fractions are those rational numbers which are written in the form $m / n$, in which $m$ and $n$ are integers $(n \neq 0)$. This kind of definition is seen in many textbooks, followed by explanations of what the symbols mean and how to manipulate with them [12]. The argument is true also in Finnish mathematics textbooks, especially in grades 7-9. In the textbooks for grades 3-6, rational numbers occur as fractions and decimal numbers, and in grades 7-9 they occur in the calculations of fractions and decimal numbers. In addition, in the textbooks, rational numbers can be represented on a number line [27]. To present " $2 / 3$ " on the number line, we divide the segment from 0 to 1 into 3 segments of equal length. Then, starting from 0 , we count 2 of these segments and stop the mark corresponding to the right endpoint second segment to obtain the point assigned to the rational number " $2 / 3$ ".

\section{The symbol "a/b" as a ratio.}

In the textbooks, pupils encounter the concept of ratio connected to the mathematical symbol " $2 / 3$ ", for example as follows: a) "the board of a certain association should have a ratio of 2 to 3 for women to men" (meaning two women members for every three men); (b) "eggs cost two euros a dozen 
(this means that every dozen eggs costs two euros); and (c) "two parts of fluid A and three parts of fluid B make a total mixture of five parts". Each of these examples illustrates a ratio [24]. The ratios are written in Finnish textbooks $\frac{a}{b}$ or $a: b$.

\section{$D$. The symbol " $a / b$ " as a division}

The symbol "a/b" can also refer to division where it focuses on the operation [24]. In Finnish textbooks, the division operation is represented either by a hyphen "-"or by a division sign ":". The division operation can be either division by parts or division by contents depending on the context [28]. In practice, the division approach could be performing division with bare numbers or a partitive division. The division " $\mathrm{a} / \mathrm{b}$ ", in which a unit of a continuous quantity is shared equally by $\mathrm{b}$ recipients, mentioning that the results of division are not always whole numbers. As a result of a division, a recurring decimal representation can often be rounded up, which is no longer the exact value that the fraction number represents. Due to this, one needs fractions to express the results [12].

\section{E. The symbol " $a / b$ " as a probability}

The symbol "a/b" can also mean probability: For an experiment with sample space $S$ with equally likely outcomes, the probability of event $\mathrm{A}$ is given by

$$
P(A)=n(A): n(S)
$$

where $n(A)$ is number of elements of $A$ and $n(S)$ is number of elements of $S$. The consequence of the definition is that

$$
0 \leq P(A) \leq 1
$$

For example, when you toss a coin, the probability of getting heads is $\frac{1}{2}$.

\subsection{The Role of Mathematics Textbooks and Teachers}

Mathematics textbooks are a powerful resource in mathematics classes (e.g., [11,29]) because they interpret the mathematics curriculum for both pupils and teachers. Finnish class teachers rely on the use of mathematics textbooks in teaching because they believe that doing so ensures that they will follow the national curriculum [22]. A similar phenomenon can be seen in the teaching of Finnish mathematics teachers, as they often see the textbook as a concrete curriculum that defines the contents of the teaching, the goals and the didactical solutions [25]. In many cases, mathematics lessons are planned and implemented through the mathematical tasks and activities found in the textbooks. For this reason, mathematics textbooks may be directly connected to the structure of teaching practice and can thus act as an implementable curriculum [30-32].

In Finland, teachers are responsible for the choice of textbooks. The textbook has a strong influence on teacher's didactical choices, but the teacher still has the option of not using it in the lessons. For example, teachers can build up the whole learning process based on pupils' individual work with the mathematics textbooks, or they may use the textbooks simply as a source of exercises and homework tasks. For mathematics learning, materials included in the textbooks comprise activities such as reading explanatory texts and acquiring new content, looking through worked examples, games, solving tasks, etc. Pupils do not actually get the opportunity to fully exploit the mathematics textbook as a multifaceted learning resource, because teachers mostly use the book as a crucial resource for exercises. Mathematics textbooks are often laid out in such a way that each page-spread is designed to be dealt with during one lesson. In addition, the ready-made tests are included as materials for the teachers. Due to this, the teacher is an implementer of a learning process that was designed and regulated by textbook authors $[25,30,33]$. 
Typically, in the Finnish textbooks every topic starts with the definitions of a new concept or content; often there are worked examples, followed by a set of tasks which could include material for several pagespreads (that means sequential lessons). For example, textbooks usually describe the ratio of the part to the whole as an area model (e.g., as a pie model), and a pie model for "2/3" would be read for example as two thirds of a pizza. Especially in the third grade, when pupils get to know the symbol " $\mathrm{a} / \mathrm{b}$ ", in textbooks, this symbol is interpreted in the context of a fraction. As previously mentioned in the Introduction, textbooks often emphasize a procedural perspective concerning the teaching of fractions, in which case "textbook driven" taught pupils will not get a clear picture of the fraction concept.

As mentioned above, Finnish mathematics teaching is "textbook driven". This often means that the nature of mathematics and the contents of school mathematics appear for pupils only through the medium of textbooks. If both the textbooks and the lessons emphasize calculations, there is no room left for the pupils to express their own thinking, for example by means of languaging. The textbooks emphasize the part-whole approach [14], but the other meanings of the fraction concept do not come through clearly. This is why it is interesting to discover what kind of meanings prospective class teachers give for the symbol " $a / b$ ".

\subsection{Meaning Making of the Concept}

The main purpose of using natural language (most often the student's mother tongue), and visual representations in learning activities (e.g., in studying new mathematical concepts and doing exercises) is to develop the student's own meaning-making processes. For example, Morgan [34] showed that writing and the use of natural language in the solutions of mathematical problems may in fact boost learning in mathematics, develop mathematical understanding, change the pupil's attitude towards mathematics for the better, and help the teacher's evaluation.

If we broaden the traditional meaning of "language", we can understand the different representations of the concept as expressions by versatile languages: mathematical symbolic language (MSL), natural language (NL) and pictorial language (PL) [28,35-37]. We call the process in which for example a pupil expresses their thinking as "languaging" [38]. We describe languaging in mathematics as referring to expressing one's mathematical thinking by different modes, either orally (by natural language), or in writing (by natural language, mathematical symbolic language, or pictorial language) [28]. We can therefore recognize three languages which mathematics textbooks use as meaning-making tools for mathematical concepts and procedures. However, we see that the three languages should also be used by the pupils; it has been shown that languaging of mathematical thinking helps pupils to structure their thinking and in that way to understand mathematical concepts and procedures $[28,34,37,39]$.

One aspect of understanding a concept is an awareness of how it is related to other concepts, and an ability to use it meaningfully in new contexts. In school mathematics, we can recognize many representations of concepts: mathematical symbolism, expressions by natural language, visual display and manipulations by concrete materials (e.g., $[10,37])$. From the point of view of a concept, we can speak of representations of the concept $[10,40]$.

When a pupil expresses their mathematical thinking, he or she can use different multimodal approaches (e.g., MSL, NL and/or PL). Theoretically, the multimodal languaging model is related to multiliteracy [41]. When a reader makes meanings for a mathematical text the languages can be seen as a multi-semiotic approach, where the different languages make it possible to construct many kinds of meanings for concepts in versatile contexts $[28,36,37]$. In this article, we concentrate on connecting mathematical symbolic language and pictorial language by interpreting students' expressions in natural language. 


\section{Research Questions and Data Collection}

\subsection{Research Questions}

During Finnish elementary school, our pupils go through all the meanings of the symbol "a/b": a fraction, a rational number, a ratio, a division or a probability. However, in school mathematics, there are rarely situations where these meanings are considered simultaneously. Our purpose is to study what meanings Finnish students find out of that list. Especially if we consider prospective class teachers, we can understand the difficulties in the conceptual learning of fractions, and find new development targets in teacher education. Therefore, it would be interesting to examine the meanings which prospective class teachers (our students in this case) have given for the mathematical symbol " $2 / 3$ ".

In this article, we concentrate on the following research questions:

1) What meanings do students give spontaneously for the symbol " $2 / 3$ "?

2) What relationships do students find for the given pictures and the symbol " $2 / 3$ "?

3) What kind of influences has the multi-semiotic approach to students' interpretations?

\subsection{Data Collection}

Our data involved 102 first-year students of two universities in Finland, 71 from the University of Tampere and 31 from the University of Jyväskylä. There were 85 female and 17 male students. The data were collected during the mathematics didactics course by questionnaires in the spring of 2017. The questionnaire had three pages:

1) On the first page, the students gave their opinions in the open question about what different meanings (e.g., fraction, division, ratio, etc.) the mathematical symbol " $2 / 3$ " can have. Several lines were provided for the answers.

2) On the second page, the students were asked to describe in natural language (Finnish) how the pictures A-D (Figure 1) are connected to the mathematical symbol "2/3". The students could give one or more descriptions of the connections.

3) On the third page, there was a mathematical problem, including the picture and the mathematical solution (Figure 2). The student's task was to explain the solution processes by natural language, and to discover whether there were any mistakes in the presentation.



Figure 1. The second question on the second page of the research questionnaire: How the pictures A-D describe mathematical symbol " $2 / 3$ ". 




Figure 2. The third question on the third page of the research questionnaire: Explain what has been done in the presentation and consider the correctness of the solution process.

The first and the second page of the questionnaire were made in the course under teachers' control. The solutions of the third page were made as homework.

The idea of the questionnaire was based on our theoretical background; from the answers, we wanted to get an understanding of the students' perceptions of the meanings of the mathematical symbol " $2 / 3$ ", and on the other hand how a multi-semiotic approach supports the interpretations.

\section{Results}

The data were analyzed by mixed methods. We used the IBM SPSS statistic 24 program for typical statistical analysis (e.g., in comparing distributions). The qualitative analysis was made by theory guided content analysis (e.g., categorizations). We used the classification into the six categories presented in the theoretical part of the article, and on the other hand the categories generated by the answers. In the first question of the questionnaire, students' $(\mathrm{N}=102)$ spontaneous understanding of the mathematical symbol " $2 / 3$ " was in most cases as a fraction (77 students gave "two thirds of a given whole" and 43 students "two of three parts"), which are typical also in the Finnish mathematics textbooks (Figure 3). Ratio, rational number or probability were mentioned the least. We have chosen typical verbal expressions as examples from every category (Figure 3):

1) Division: "Two divided by three: two pizzas to be divided into three people." (Student 89),

2) Fraction 1: "In the test I got two thirds of answers correct". (Student 55),

3) Fraction 2: "Two out of three. Pekka has eaten two pizza pieces from three." (Student 87),

4) Probability: "Can be used to describe probability." (Student 76),

5) Rational number: “0.66 ..." (Student 92),

6) Ratio: "You'll get good juice if you put 2 dl concentrate and $3 \mathrm{dl} \mathrm{water"} \mathrm{(Student} \mathrm{57).}$

When we counted how many different meanings each prospective class teacher $(\mathrm{N}=102)$ found in Question 1 on the first page (spontaneously answered) and in Question 2 on the second page (pictorial guided, see Figure 1) of the questionnaire, we got the distributions of the totals in Figure 4 . The correlation (Pearson $r=0.245)$ between the distributions in Figure 4 is significant $(p<0.05)$. The second distribution (pictorial) is significantly $(p=0.000)$ better than the first one (Wilcoxon signed rank test: $Z=-8.168)$. 


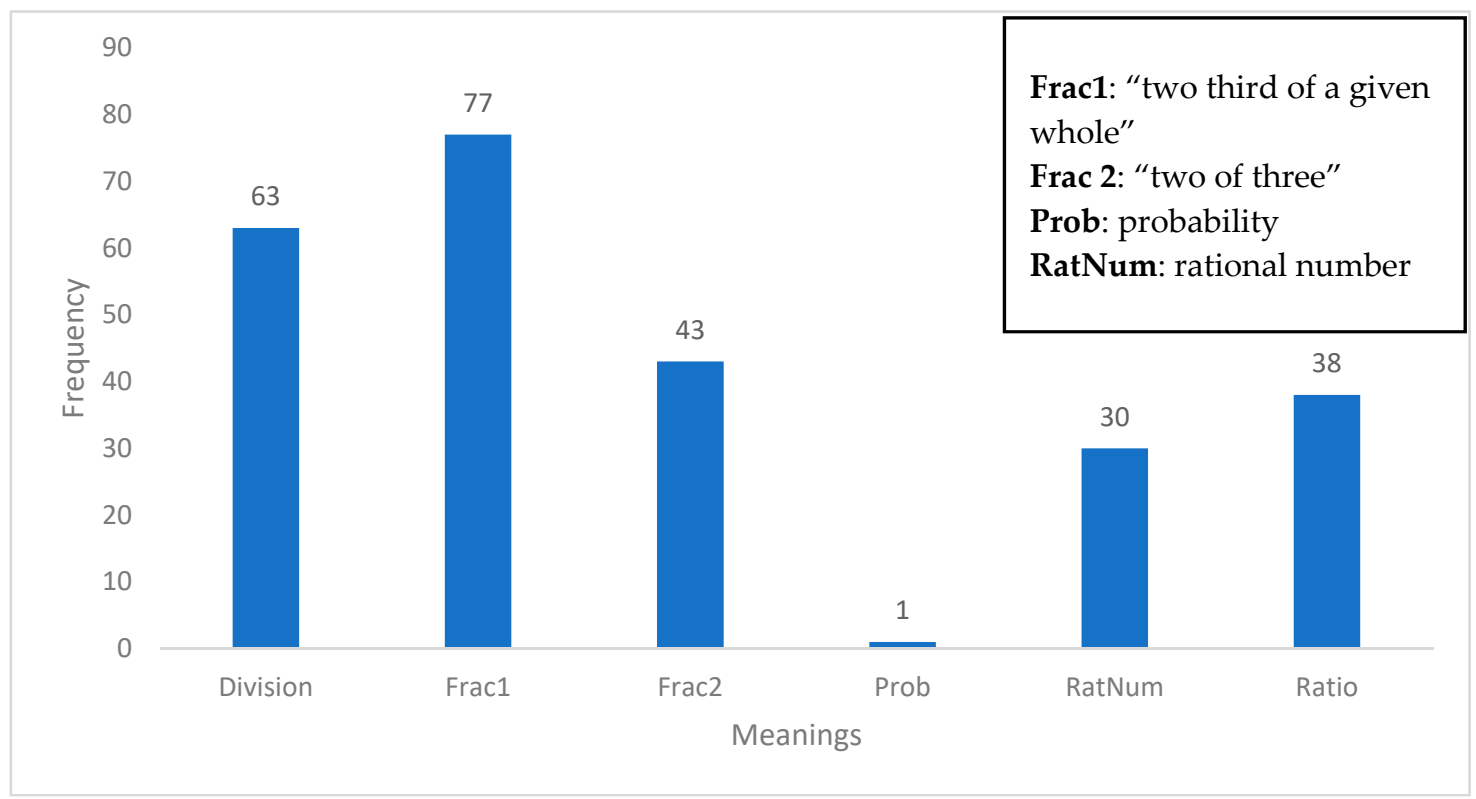

Figure 3. The meanings the students $(\mathrm{N}=102)$ gave for the mathematical symbol (Question 1 on the first page of the questionnaire).

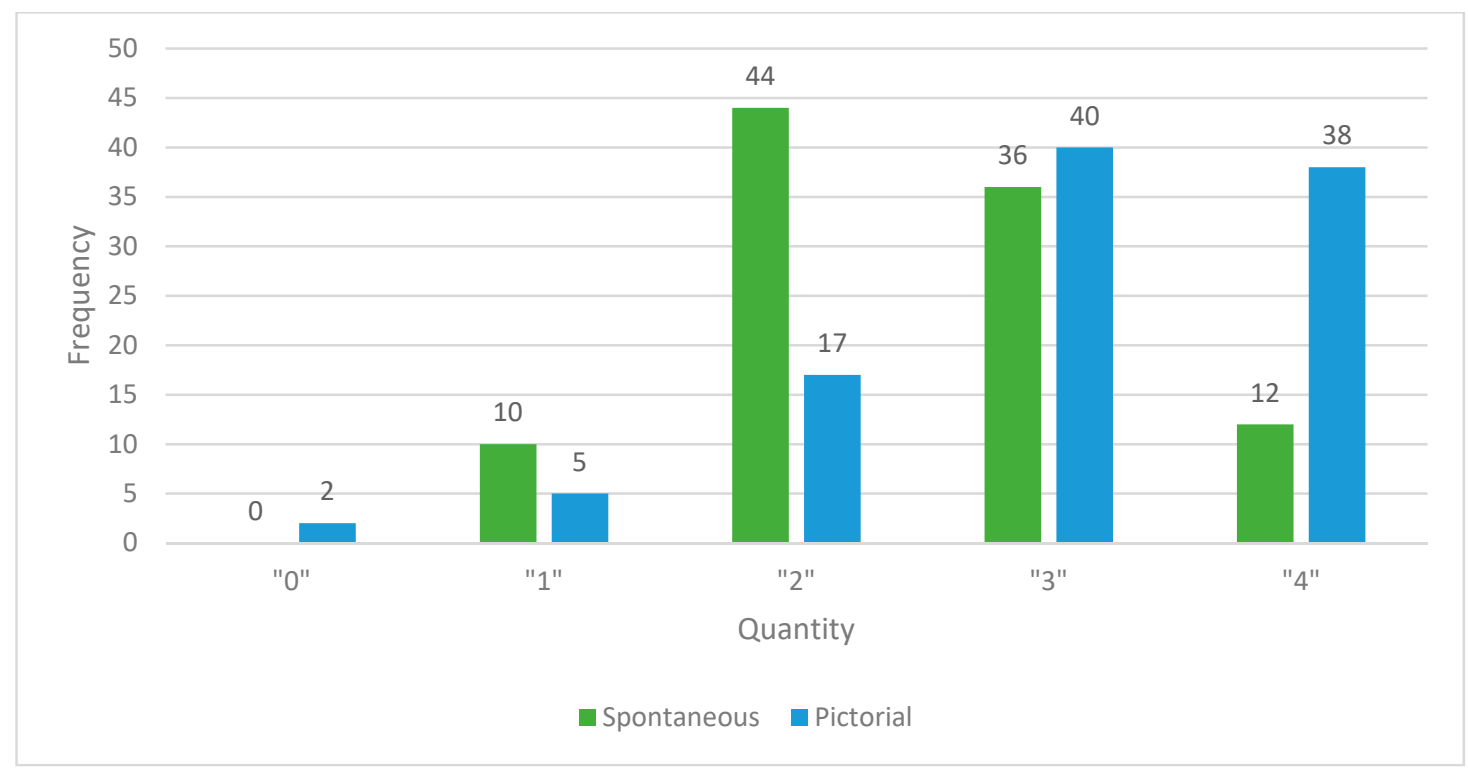

Figure 4. Distributions of totals of different meanings the students $(\mathrm{N}=102)$ given spontaneously (Question 1 on the first page of the questionnaire), and to the given pictures A-D (Question 2 on the second page of the questionnaire), for the mathematical symbol " $2 / 3$ ". For example quantity " 2 " means, that 44 students found exactly two different meanings for the symbol " $2 / 3$ " in Question 1 and 17 students in Question 2. 
The pictures (see Figure 1) associated with the mathematical symbol " $2 / 3$ " gave more effective meanings for the students than a purely mathematical symbol. Picture A (Figure 1) had the most, and picture $B$ the fewest interpretations of the six categories (Table 1). The concept of ratio seems to be the most difficult to connect with the mathematical symbol " $2 / 3$ ". An interesting feature in the interpretations of picture B was that 13 students supposed that picture B does not connect in any way to the given mathematical symbol, that instead of " $2 / 3$ " there should be " $2 / 5$ ", and that the interpretation of the connection is a fraction illustration.

Table 1. Frequencies of the students' $(\mathrm{N}=102)$ interpretations how mathematical symbol " $2 / 3$ " is connected to pictures A-D (Figure 1, Question 2 on the second page of the questionnaire).

\begin{tabular}{ccccc}
\hline Picture & A & B & C & D \\
\hline Frac1 & 59 & 0 & 18 & 45 \\
Frac2 & 38 & 0 & 0 & 0 \\
Ratio & 2 & 43 & 0 & 0 \\
Division & 1 & 1 & 56 & 1 \\
Rational & 3 & 0 & 1 & 41 \\
Other & 16 & 49 & 15 & 8 \\
\hline
\end{tabular}

In the answers to the third question on the third page of the questionnaire, students expressed mathematical meanings on the basis of a picture (Figure 2) in which different languages (MSL, NL, and $\mathrm{PL}$ ) give possibilities for multimodal interpretations. In the data analysis of the third question, we used a classification into categories generated by the answers. The answers of the third question (Figure 2) were divided into four themes (Table 2): (1) meanings of the symbols " $\frac{1}{2}$ " and " $\frac{2}{3}$ " (52 references in the answers); (2) conceptual approach to the expressions ( references in the answers); (3) procedural approach to the expressions (81 references in the answers); and (4) do not find any problems in the presentation (35 references in the answers). Before making the themes, we divided the answers into categories, and, finally, put these categories into the appropriate thematic areas as follows: the first theme (1a, $1 b$, and 1c; see Table 2), the second theme (2a and 2b; see Table 2), the third theme ( $3 a, 3 b, 3 c$, and 3d; see Table 2), and the fourth theme (4; see Table 2). Many students gave meanings for symbols “立" and " $\frac{2}{3}$ " as a "part of whole" approach (see Section 2.1, part A items A1 and A2, e.g., Students 98,96 and 92) in the categories $1 \mathrm{a}, 1 \mathrm{~b}$ and $1 \mathrm{c}$ (Table 2). Only a few students reached a conceptual level in their analysis of the given expression “ $\frac{1}{2}+\frac{2}{3}$ " (categories $2 a$ and $2 b$, e.g., Students 93 and 88 ). Clearly, the concept of ratio was extremely difficult to find for most of the students. On the other hand, most students did find the mistake in the equation " $\frac{1}{2}+\frac{2}{3}=\frac{1+2}{2+3}$ " (3a). Some of the students (category 3b, e.g., Student 89 ) understood the idea of the expression " $\frac{1+2}{2+3}$ ". The procedural point of view is seen in the categories $3 \mathrm{c}$ and $3 \mathrm{~d}$ (e.g., Students 79 and 85), where the "correct answer " $\frac{7}{6}$ " plays the main role. Only 13 students (category $3 \mathrm{~d}$ ) began to query the connection between the answer " $\frac{7}{6}$ " and the figure (Figure 2). The most thought-provoking category is category 4 in the fourth theme, because 35 students did not find any problems in the presentation (see Figure 2).

In Table 2, the respondents are from two universities (Jyväskylä university and Tampere University) and the answers are randomly chosen. Table 2 presents representative answers (answers for the Question 3 of the questionnaire) as a data example from each subcategory of the theme. 
Table 2. Frequencies of the students" $(\mathrm{N}=102)$ interpretations how mathematical symbol " $2 / 3$ " is connected to pictures A-D (Figure 3).

\begin{tabular}{|c|c|c|c|}
\hline Theme & Category & $f$ & Example \\
\hline \multirow{3}{*}{$\begin{array}{l}\text { Meanings of the } \\
\text { symbols " } \frac{1}{2} " \\
\text { and " } \frac{2}{3} \text { " }\end{array}$} & $\begin{array}{l}\text { the ratio of the number } \\
\text { of white balls to the } \\
\text { number of balls (1a) }\end{array}$ & 7 & $\begin{array}{l}\text { Ratio between white balls to red balls (two big balls in the top ok) } \\
\text { (Student 98) }\end{array}$ \\
\hline & $\begin{array}{l}\text { white balls one-two of } \\
\text { all balls (1b) }\end{array}$ & 19 & $\begin{array}{l}\text { The white balls represent the numerator, i.e., how many parts have } \\
\text { been taken, and all the balls represent the denominator, i.e., how } \\
\text { many parts are in total. (Student } 96 \text { ) }\end{array}$ \\
\hline & $\begin{array}{l}\text { one white ball of two } \\
\text { balls (1c) }\end{array}$ & 26 & $\begin{array}{l}\text { One of the two balls is red and two of the three balls are white. } \\
\text { (Student 92) }\end{array}$ \\
\hline \multirow{2}{*}{$\begin{array}{l}\text { Conceptual } \\
\text { approach to the } \\
\text { expressions }\end{array}$} & $\begin{array}{l}\text { “位 }+\frac{2}{3} \text { " is not correct } \\
\text { expression for addition } \\
\text { of two ratios }(2 \mathrm{a})\end{array}$ & 2 & $\begin{array}{l}\text { The pupil has mixed with the amount of proportionality that is } \\
\text { significant to each other. In the above fractions, the numerator } \\
\text { does not, for example, express the number of things per se, but it is } \\
\text { the ratio representing the proportion of the total or proportionality } \\
\text { relative to the total. Therefore, before adding one would have } \\
\text { needed to find common denominators rather than adding the } \\
\text { denominators together. (Student 93) }\end{array}$ \\
\hline & $\begin{array}{l}\text { “1 } \frac{1}{2}+\frac{2}{3} " \text { is not correct } \\
\text { addition, because the } \\
\text { fractions have been } \\
\text { taken from different } \\
\text { totals }(2 \mathrm{~b})\end{array}$ & 2 & $\begin{array}{l}\text { The balls are combined, that is, the whole has changed into five } \\
\text { balls (combined the amounts of balls in the two bigger balls), of } \\
\text { which white is still } 1+2 \text { i.e., a total of } 3 \text { (the same amount as in } \\
\text { the two big balls in total). Overall, the total number of small balls } \\
\text { has changed. (Student } 88 \text { ) }\end{array}$ \\
\hline \multirow{4}{*}{$\begin{array}{l}\text { Procedural } \\
\text { approach to the } \\
\text { expressions }\end{array}$} & $\begin{array}{l}\text { find the mistake in the } \\
\text { equation " } \frac{1}{2}+\frac{2}{3}=\frac{1+2}{2+3} " \\
\qquad(3 a)\end{array}$ & 31 & $\begin{array}{l}\text { In the picture under the third ball the fractions are added together } \\
\text { without considering the whole. You cannot add fractions with } \\
\text { different denominators together before finding them common } \\
\text { denominators. (Student } 84 \text { ) }\end{array}$ \\
\hline & $\begin{array}{l}\text { the expression " } \frac{1+2}{2+3} \text { " is } \\
\text { argumented correctly } \\
\qquad(3 \mathrm{~b})\end{array}$ & 19 & $\begin{array}{l}\text { In the picture, at point } C \text { the balls of points } A \text { and } B \text { are combined, } \\
\text { and this forms a new whole at point } C \text {. When counting the selected } \\
\text { white balls of } A \text { and } B \text {, three balls are obtained. } \\
\text { Unselected balls }=2 \text {. The total amount of balls at point } C \text { is } 5 \text {, } \\
\text { so three white balls out of five have been selected in total. } \\
\text { (Student } 89 \text { ) }\end{array}$ \\
\hline & $\begin{array}{l}\text { The sum should be } \frac{7}{6} \\
\text { (3c) }\end{array}$ & 18 & $\begin{array}{l}\text { Oh! This math task } \frac{1}{2}+\frac{2}{3} \text { is incorrectly calculated. } \\
\text { If the denominators are different, then to add fractions you must } \\
\text { first get common denominators. Then you can add the fractions } \\
\frac{1}{2}+\frac{2}{3}=\frac{3}{6}+\frac{4}{6}=\frac{7}{6}=1 \frac{1}{6} \text { (Student } 79 \text { ) }\end{array}$ \\
\hline & $\begin{array}{l}\text { The sum is } \frac{7}{6} \text {, but there } \\
\text { is something wrong } \\
\text { with the figure (3d) }\end{array}$ & 13 & $\begin{array}{l}\text { In the picture the fractions } \frac{1}{2} \text { and } \frac{2}{3} \text { are added together but in the } \\
\text { wrong way. Fractions must have the same denominators before } \\
\text { adding. After finding denominators they can be counted together. } \\
\frac{1}{2}+\frac{2}{3}=\frac{3}{6}+\frac{4}{6}=\frac{7}{6}=1 \frac{1}{6} \text { In the picture the balls are counted } \\
\text { together, but not as fractions. (Student 85) }\end{array}$ \\
\hline $\begin{array}{l}\text { Do not find any } \\
\text { problems in the } \\
\text { presentation }\end{array}$ & $\begin{array}{l}\text { Accept the } \\
\text { presentation }(4 a)\end{array}$ & 35 & $\begin{array}{l}\text { This illustrates addition of fractions and especially that why you } \\
\text { can add numerators together and denominators together. At first, } \\
\text { I did not understand what it was all about when I was just staring } \\
\text { at red balls. It would have been clearer if the colored balls had } \\
\text { described the amount of numerator. On the other hand, this } \\
\text { version made me think more. (Student } 77 \text { ) }\end{array}$ \\
\hline
\end{tabular}

\section{Conclusions and Discussion}

As expected, the typical understanding of the mathematical symbol " $2 / 3$ " was as a fraction ("two thirds of a given whole" and "two from three"), because that meaning is emphasized in the curriculum and in the textbooks. Ratio, rational number or probability were far less common (Figure 3 and Table 1). When students had the mathematical symbolic text and picture together (a multi-semiotic approach to a concept by pictorial language), it was easier for them to find meaningful interpretations expressed by natural language (Figure 4 and Table 1). The concepts of ratio and rational number especially were better found by connecting pictures (B and D) with the mathematical symbol " $2 / 3$ ", than only spontaneously from the symbol " $2 / 3$ " (Table 1 ). Apparently, the concept of ratio is difficult 
for Finnish prospective class teachers and pupils despite a multi-semiotic approach (e.g., Figure 2 and Table 2). By constructing a meaningful context (natural language) for the aforementioned concepts, the students demonstrate their understanding of them and also deepen it. As mentioned before in the theoretical section (section 2), especially in the third grade, when pupils are introduced to symbols, the symbol " $\mathrm{a} / \mathrm{b}$ " is interpreted in the textbooks in the context of a fraction. If the textbooks emphasize this interpretation, and a procedural perspective concerning the teaching of fractions, it may happen that in "textbook driven" teaching pupils will not achieve a deep understanding of the different meanings of the fraction concept [42]. Where textbooks have such a crucial role in defining mathematics teaching and learning, we have to develop them, and other learning materials, from the point of view of sustainable development in learning mathematical concepts and structures. In addition, the FCC [5] highlights that all activities must reinforce educational equity and equality and improve the pupils' learning-to-learn skills and capabilities for lifelong learning. This is important perspective in the point of view of the development work concerning textbooks and other learning materials.

We can see on the basis of the results that the fraction and its approximate concepts should be based on a multi-semiotic approach. The learning material should combine natural and pictorial language with mathematical symbol language both in the concepts learning, and in the perception of the learner's thinking. When the meanings of the concept are understood individually, the learner's metacognitive skills of the aforementioned concepts should be developed simultaneously with the different languages. In this way, we can help the learner to a better understanding of the relationships between concepts. The understanding of mathematical concepts and the relationships between concepts will build bridge to the sustainable development (e.g., impact on lifelong learning) from the point of view of teaching and learning.

Based on the results of this study, it may be concluded that the designers of learning materials should think especially about the ways in which they could present the multiple meanings of the fraction concept, so that it would become more comprehensible and accessible for teachers and pupils. Further studies of the impacts of different learning materials on learning outcomes of the fraction concept would undoubtedly be needed for this multifaceted phenomenon to be properly understood. In particular, it is important to study and discuss the ways in which deep understanding and creative reasoning could be better emphasized, rather than imitative reasoning and the inculcation of routines.

Based on our results, we can see that prospective class teachers have problems in understanding the fraction concept and the related concepts from the point of view of the symbol " $2 / 3$ " (Tables 1 and 2, Figures 3 and 4). We suggest that, in teacher training, it is important for prospective class teachers to be aware that understanding the multiple meanings of fractions is not trivial. As a part of their teacher education, the mathematics content courses for prospective class teachers need to address these issues, and thus they could provide an adequate opportunity to develop a sound content knowledge through their own meaning-making processes, and knowledge for their pupils in primary school.

Our study shows clear pedagogical shortcomings in the teaching of the fractional concept (including also textbooks). If prospective class teachers' mathematical content knowledge and pedagogical content knowledge become more sustainable through pedagogical arrangements in teacher education, this will contribute to the building of a sustainable mathematical basis for future generations. This can also reduce the anxiety associated with learning the meaning of a fraction. As the conclusion, we suggest: (1) developing of mathematical learning materials based on pedagogical content knowledge; (2) strengthening of prospective class teachers' subject matter content knowledge in mathematics (especially conceptual knowledge); and (3) studying of pedagogical content knowledge of school mathematics (especially in what order we teach mathematical concepts and how we should show the relations between them). We believe that these suggestions would improve sustainable development in mathematics education. 
Author Contributions: J.J. and P.P. are equal writers of the article: conceptualization, methodology, formal analysis, investigation, resources, data curation, writing-original draft preparation, writing-review and editing, and visualization.

Funding: This research received no external funding.

Conflicts of Interest: The authors declare no conflict of interest.

\section{References}

1. Zehetmeier, S.; Krainer, K. Ways of promoting the sustainability of mathematics teachers' professional development. ZDM Math. Educ. 2011, 43, 875-887. [CrossRef]

2. UN. The 2030 Agenda for Sustainable Development. Sustainable Development Goals. 2018. Available online: https:/ / sustainabledevelopment.un.org/sdgs (accessed on 15 August 2018).

3. Díez-Palomar, J.; de Sanmamed, A.F.F.; García-Carrión, R.; Molina-Roldán, S. Pathways to equitable and sustainable education through the inclusion of roma students in learning mathematics. MDPI Sustain. 2018, 10, 2191. [CrossRef]

4. Shulman, L.S. Those who understand: Knowledge growth in teaching. Educ. Res. 1986, 15, 4-14. [CrossRef]

5. Opetushallitus. Finnish Core Curriculum for Basic Education 2014. Available online: http://www.oph.fi/ ops2016/perusteet (accessed on 15 August 2018).

6. Joutsenlahti, J.; Vainionpää, J. Oppimateriaali matematiikan opetuksessa ja osaamisessa. In Miten Matematiikan Taidot kehittyvät? Matematiikan Oppimistulokset Peruskoulun Viidennen Vuosiluokan Jälkeen Vuonna 2008; Niemi, T.E.K., Metsämuuronen, J., Eds.; Opetushallitus, Koulutuksen Seurantaraportti: Helsinki, Finland, 2010; Volume 2, pp. 137-148.

7. Petoz, P.; Reid, A. What on earth is sustainability in mathematics? N. Z. J. Math. 2003, 32, 135-144.

8. Lortie-Forgues, H.; Tian, J.; Siegler, R.S. Why Is Learning Fraction and Decimal Arithmetic So Difficult? Dev. Rev. 2015, 38, 201-221. [CrossRef]

9. Matematiikan Oppimistulokset Peruskoulun Viidennen Vuosiluokan Jälkeen Vuonna 2008; Opetushallitus: Helsinki, Finland, 2010; pp. 137-148.

10. Prediger, S.; Wessel, L. Fostering German-language learners' constructions of meanings for fractions-Design effects of a language- and mathematics integrated intervention. Math. Educ. Res. J. 2013, 25, 435-456. [CrossRef]

11. Mullis, I.V.S.; Martin, M.O.; Foy, P. TIMSS 2007 International Mathematics Report: Findings from IEA's Trends in International Mathematics and Science Study at the Fourth and Eighth Grades; Chestnut Hill: Boston College, MA, USA, 2008.

12. Park, J.; Güler, B.; McGrory, R. Teaching prospective teachers about fractions: historical and pedagogical perspectives. Educ. Stud. Math. 2013, 82, 455-479. [CrossRef]

13. Iskenderoglu, T.A. Multiplication and division problems posed by pre-service elementary mathematics teachers about fraction topic. In Proceedings of the 40th Conference of the International Group for the Psychology of Mathematics Education, Szeged, Hungary, 3-7 August 2016; Csíkos, C., Rausch, A., Szitányi, J., Eds.; PME: Szeged, Hungary, 2016; Volume 2, pp. 35-42.

14. Joutsenlahti, J.; Perkkilä, P.; Tossavainen, T. Näytteitä murtoluvun käsitteestä eri aikakausien oppikirjoissa. In Proceedings of the Annual FMSERA Symposium 2016, Joensuu, Finland, 27-28 October 2016; Asikainen, M., Hirvonen, P., Eds.; pp. 99-109.

15. Merenluoto, K. Matkalla käsitteellisen muutoksen prosessikuvaukseen matematiikassa. On the way to the process description of conceptual change in mathematics. In Kasvatuksen Yhteisöt-Uupumusta, Häirintää vai Yhteisöllistä Kasvua? Sinevaara-Niskanen, H., Rajala, R., Eds.; Lapin Yliopiston Kasvatustieteellisiä Julkaisuja: Turku, Finland, 2006; pp. 58-71.

16. Vosniadou, S. Conceptual change research: state of art and future directions. In New Perspectives on Conceptual Change; Schnotz, W., Vosniadou, S., Carretero, M., Eds.; Elsevier Science: Killington/Oxford, UK, 1999; pp. 3-14.

17. Vosniadou, S. Capturing and modelling the process of conceptual change. Learn. Instr. 1994, 4, 45-69. [CrossRef] 
18. Vamvakoussi, X.; Vosniadou, S. What mental models do students use regarding the structure of the domain of rational numbers? In International Group of the Psychology of Mathematics Education, Proceedings of the 26th Annual Conference, Norwich, UK, 21-26 July 2002; Cockburn, A.C., Nardi, E., Eds.; University of East Anglia: Norwich, UK, 2002; pp. 1-326.

19. Valverde, G.A.; Bianchi, L.J.; Wolfe, R.G.; Schmidt, W.H.; Houang, R.T. According to the Book: Using TIMSS to Investigate the Translation of Policy into Practice through the World of Textbooks; Kluwer: Dordrecht, The Netherlands, 2002.

20. Viholainen, A.; Partanen, M.; Piiroinen, J.; Asikainen, M.; Hirvonen, P.E. The role of textbooks in Finnish upper secondary school mathematics: theory, examples and exercises. Nordic Stud. Math. Educ. 2015, 20, 157-178.

21. Holmlund, A. Lärobokens Betydelse vid Lektionsplanering: En Intervjustudie med åtta Finska och Svenska Matematiklärare [The Importance of Textbook on Planning of Lessons: An Interview Study with Eight Finnish and Swedish Mathematics Teachers]. Bachelor's Thesis, University of Gothenburg, Gothenburg, Sweden, 2013. Available online: http://ncm.gu.se/media/luma/GE-2013/holmlund.pdf (accessed on 15 August 2018).

22. Perkkilä, P. Oppikirja ja uskomukset alkuopettajien matematiikan opetuksessa [Textbook and beliefs in teaching first- and second-grade mathematics]. In Tutkimus Kouluopetuksen Kehittämisessä [Research in the Development of School Teaching]; Ahtineva, A., Ed.; Publications of the Faculty of Education, University of Turku: Turku, Finland, 2001; Volume 17, pp. 112-125.

23. Pantziara, M.; Philippou, G. Levels of students' "conception" of fractions. Educ. Stud. Math. 2012, 79, 61-68. [CrossRef]

24. Stewart, V. Making Sense of Student's Understanding of Fractions: An Exploratory Study of Sixth Graders' Construction of Fraction Concepts through the Use of Physical Referents and Real-World Representations. 2005. Available online: http:/ / purl.flvc.org/fsu/fd/FSU_migr_etd-0390 (accessed on 15 August 2018).

25. Mikkilä-Erdmann, M.; Olkinuora, E.; Mattila, E. Muuttuneet käsitykset oppimisesta ja opettamisesta-Haaste oppikirjoille [Changed conceptions of learning and teaching-A challenge for textbooks]. Kasvatus 1999, 30, 436-449.

26. Beckmann, S. Mathematics for Elementary Teachers, 2nd ed.; Addison Wesley: Boston, MA, USA, 2008.

27. Siegler, R.S.; Fazio, L.K.; Bailey, D.H.; Zhou, X. Fractions: The new frontier for theories for numerical development. Trends Cogn. Sci. 2013, 17, 13-19. [CrossRef] [PubMed]

28. Joutsenlahti, J.; Kulju, P. Multimodal languaging as a pedagogical model-A case study of the concept of division in school mathematics. Educ. Sci. 2017, 7, 9. [CrossRef]

29. Berger, M. Reading and learning from Mathematics textbooks: an analytic framework. In Proceedings of the 40th Conference of the International Group for the Psychology of Mathematics Education, Szeged, Hungary, 3-7 August 2016; Csíkos, C., Rausch, A., Szitányi, J., Eds.; PME: Szeged, Hungary, 2016; Volume 2, pp. 83-90.

30. Lepik, M.; Grevholm, B.; Viholainen, A. Using textbooks in the mathematics classroom-The teachers' view. Nordic Stud. Math. Educ. 2015, 20, 129-156.

31. Silver, E.A. Cross-national comparisons of mathematics curriculum materials: what might we learn? ZDM Int. J. Math. Educ. 2009, 41, 827-832. [CrossRef]

32. Törnroos, J. Mathematics textbooks, opportunity to learn and student achievement. Stud. Educ. Eval. 2005, 31, 315-327. [CrossRef]

33. Perkkilä, P. Opettajien matematiikkauskomukset ja matematiikan oppikirjan merkitys alkuopetuksessa. In Jyväskylä Studies in Education, Psychology and Social Research; Jyväskylän yliopisto: Jyväskylä, Finland, 2002.

34. Morgan, C. The place of pupil writing in learning, teaching and assessing mathematics. In Issues in Mathematics Teaching; Gates, P., Ed.; Routledge: London, UK, 2001; pp. 234-244.

35. Pimm, D. Speaking Mathematically: Communication in Mathematics Classrooms; Routledge \& Kegan Paul: London, UK, 1987.

36. Lemke, J. Mathematics in the Middle: Measure, Picture, Gesture, Sign and Word. In Educational Perspectives on Mathematics as Semiosis: From Thinking to Interpreting to Knowing; Andersson, M., Saenz-Ludlow, A., Zellweger, S., Cifarelli, V., Eds.; Legas Publishing: Ottawa, ON, Canada, 2002; pp. 215-243.

37. Schleppegrell, M. Language in mathematics teaching and learning: a research review. In Language and Mathematics Education; Moschkovich, J.N., Ed.; Information Age Publishing, Inc.: Charlotte, NC, USA, 2010; pp. 73-112. 
38. Bauersfeld, H. Language games in the mathematics classroom: Their function and their effects. In The Emergence of Mathematical Meaning: Interaction in Classroom Cultures; Cobb, P., Bauersfeld, H., Eds.; Erlbaum: Hillsdale, NJ, USA, 1995; pp. 271-294.

39. Joutsenlahti, J. Matematiikan kirjallinen kielentäminen lukiomatematiikassa. In Ajankohtaista Matemaattisten Aineiden Opetuksen ja Oppimisen Tutkimuksessa, Proceedings of the Annual Symposium of the Finnish Mathematics and Science Education Research Association, Joensuu, Finland, 22-23 October 2009; Asikainen, M., Hirvonen, P., Sormunen, K., Eds.; Kopijyvä: Joensuu, Finland, 2009; pp. 3-15.

40. Duvall, R. Understanding the Mathematical Way of Thinking-The Registers of Semiotic Representations; Springer International Publishing AG: Cham, Switzerland, 2017.

41. Kalantzis, M.; Cope, B. Literacies; Cambridge University Press: Cambridge, UK, 2012.

42. Perkkilä, P.; Joutsenlahti, J.; Sarenius, V.-M. Peruskoulun matematiikan oppikirjat osana oppimateriaalitutkimusta. In Matematiikka ja Oppiminen; Joutsenlahti, J., Silfverberg, H., Räsänen, P., Eds.; NMI: Jyväskylä, Finland, 2018; pp. 344-364.

(C) 2019 by the authors. Licensee MDPI, Basel, Switzerland. This article is an open access article distributed under the terms and conditions of the Creative Commons Attribution (CC BY) license (http://creativecommons.org/licenses/by/4.0/). 